N. Chernukha, Dr. of Pedagogy, professor Taras Shevchenko National University of Kyiv, Kyiv, Ukraine, ORCID iD 0000-0002-5250-2366 Ali Shaheid Anad, Dr. Lecturer. Southern Technical University Nassiria Technical Institute. Iraq. ORCID iD 0000-0002-1436-6332

\title{
PRIORITY VECTORS OF PROFESSIONAL TRAINING OF MODERN SPECIALISTS IN FINE ART
}

The priority vectors of professional training of contemporary specialists of fine arts in the educational environment of higher education institutions are considered in the article. It is noted that in the modern labor market employers are not interested in a set of theoretical knowledge, but professional competence, which is the basis for successful professional self-realization of modern specialists, including specialists in fine arts, which helps them to solve successfully the problems in social and pedagogical activity as a part of the professional field.

The essence of competence approach in professional training of specialists as an important methodology of reform and modernization changes is investigated and revealed. It is noted that the process of professional training of specialists in fine arts requires certain changes in a number of segments of educational theory and practice: in values, in the goal, in the results of the educational process, in its content, forms, methods, means of education in interaction with the external environment. Attention is paid to the fact that the professional training of the specialist of fine arts will be productive, if it will be formed as a coherent system and all components of which will be maximally integrated into a single whole and focused on the implementation of basic professionally significant goals, practical activities of modern specialists in social and practical education.

The importance of successful social space of an educational institution in the process of qualitative training of specialists of fine arts is substantiated, the signs of modern social space are determined: intellectual work of students, coordinated interaction, creative cooperation, correctness of interpersonal relations, mutual respect, psychological comfort, freedom of participation.

Keywords: competence, educational space, modern specialist, integrity, professional training.

Introduction. In the fast-paced rhythm of the 21 st century, the modern vectors of the educational space remain indisputable: democratization, humanization and humanitarization, integration into the international educational space, which significantly changes the philosophy of modern education, in particular, higher education, and accordingly, new requirements for the professional level of the graduate are put forward.

In the modern labor market, employers are interested not in a set of theoretical knowledge, but competence in such fields of activity as: intellectual, legal, communicative, information, public, which help the specialist to solve problems arising in the course of professional activity independently and successfully.

The quality of vocational education today is extremely relevant and important for all sectors of human life.

In the context of the above-mentioned topical sense, the process of competence-based approach to education is becoming a key methodology for its modernization. This process requires certain changes in all branches of educational practice: in values, goals and results of education, in its content, forms, methods, methods of teaching, in technologies, in interaction with the external environment.

The purpose of the article is to investigate the priority vectors of professional training of modern professionals in fine arts and to highlight the role of the competence approach in the educational environment of higher education institutions.

Analysis of research and publications.

Recently, a number of scientific researches were carried out in Ukraine on the problems of profesionals' training and the skills approach in the educational space: B. Barkasi, N. Bibik S. Burdynska, L. Voloshko, I. Drach, O. Kotenko, G. Melnychenko, O. Piekhota, I. Halymon, L. Horuzha, S. Sysoieva, N. Chernukha.

In the current context, the need to change the educational process in modern institutions of higher education in the direction of free transition from classical training to professional expression in real working conditions, to successful professional and life self-realization of each personality remains important.It's the most important for professionals in art and fine arts and plays an important role in socialization of every individual.
The public need for a comprehensively developed, competent personality determines the goals, tasks, organizational and content structure of all units of modern education, especially vocational training.

Therefore, modern specialists who are the objects of a holistic educational process in higher education institutions should be aware that becoming a spiritually mature, competent, competitive person means having a social and moral position, being responsible for this position and affirming it with their actions, behaviour, and being aware of the personal involvement in local, national and world society [1]

It's important that the all-encompassing transformation of the education sector in the modern world is aimed, first and foremost, at transforming education into a system capable of self-regulation, in line with the challenges of modern society, constantly changing. Modern education is rapidly evolving into an innovative environment that produces modern professionals able to acquire skills for life, successfully apply them in practical activities, conscious, socially active citizens, competitive in the domestic, European and world labor markets [2].

Education should be a guarantee of high social standards of social life. The implementation of these tasks for education can be carried out in different ways, through the variety of educational institutions, forms, methods of the educational process, the introduction of effective management. The unifying phenomenon of the above is the integrity of the educational process [3].

The effectiveness of the educational process is ensured provided that it is implemented in the context of a holistic space. An education oriented to the formation of a specialist not just a knower but a competent, education oriented to the formation of the learner's personality, to provide the conditions for forming his own trajectory of professional formation is a modern education. The most important factor in the realization of education at such a level is the presence of a holistic educational space, implemented at the target, meaningful, procedural levels. In the presence of such space, it is advisable for students to use all the methods of fine art that exist in the educational space, which is an important segment of both the process of training and the socialization of every individual [4].

The space of an educational institution should be holistic, humanitarian. The main subjects of its formation are teachers 
and students, working as a 'team', systemic education, united by one goal, common common standards of educational activity. The efficiency of the formation of such a space depends directly on the level of formation of the educational space in the institutions. It is at the level of the educational institution that the transformation of the general state standards into a specific institution occurs. The institutions of governance provide optimization of this process, taking into account the features of a particular educational institution [5].

Educational institutions become real co-authors of the whole space, and not simply 'implementers'of the set standards or the proposed concept of educational activity. It is at the level of the region that the scientific potential is combined and its direction is directed towards the solution of specific practically significant tasks. System in the system (space in space), starting from the micro space at the level of work of the teacher, faculty, high school, region - to the state, European or world space [4].

Conflict-free integration into the European educational space presupposes the preservation of national, regional identity, the provision of a scientifically sound, logically engineered transition to the set standards, with the maximum orientation to the features and the real level of education, in a particular country, society. Professionals in art specialties, especially fine arts are called to play a decisive role here [6].

It is worth noting that integration into the European educational space should provide for the need for qualitative educational reform in the state. Today, the process of transition to a new formula of educational activity is difficult and often problematic.

Productive pedagogical activity is creative in its essence, it is necessarily formed on the basis of 'I-concept' and any innovations will have a positive effect if they are 'adapted' to the existing experience of professional activity. Consequently, innovations dictated by the 'top' often conflict with the teacher's actual experience, or suppress the personal component of his or her activity, or are defined as incapacitated and virtually ignored. There is a way to remove this level of conflict: to put the teacher in the position of a real subject of reforming his own concept, technology of professional activity in the context of new educational standards. And such work can be attributed to the rank of fullfledged scientific activity, the subject of which is its own activity in the complex of all its components: goals, principles, content, technologies, diagnostics, efficiency analysis, skill. On the basis of common logic, each teacher should form its own transition program, as well as its own program to increase the level of competence (according to the starting level and personal potential), to ensure competitiveness in the educational services market. Thus, irrespective of the profession, every teacher acquires real competence and joins the scientific search in the field of educational activity [7].

The transition to a qualitatively new and integral holistic educational process involves a number of priority functions: the corresponding vertical of scientific activity is built up: from basic academic institutes developing fundamental problems in scientific institutions and educational centres accumulating high potential of the respective region - to centers of scientific activity, concentrated in educational institutions levels .; the teacher feels the subject of education reformation, since it is realistically integrated through the centers at the level of educational institutions in the process of comprehending new educational standards and designing technology for their implementation in the practice of professional activity; the process of interaction between the various branches and levels of scientific activity is intensifying, as they all come together around a common program of transition to the standards of innovative education, there are many problems regarding the roughness, lack of relevant information and, in general, issues arising in practical activities and requiring appropriate interpretations, accordingly, additional research; all without exception teachers, teachers, students become researchers, become involved in scientific activity. This problem is especially relevant because it is a research work that has the highest potential for professional growth of modern professionals, especially in the field of fine arts [6].

This intensifies the process of scientific, and therefore professional interaction of teachers, is determined directly by the needs of the activity, and professional communication is a powerful factor in the formation of a holistic educational space in the educational institution, ensuring a coordinated interaction of all teachers as subjects of the system, ensuring the purposeful development of their standards quality education.

So, the foundations of forming a complete educational space are set at all levels. The system-forming element is scientific activity (as the basic mechanism of optimization of educational activity), which not only has the abovementioned potential of integration of all components of space, but also theoretically substantiates the process of ascension to new education, attracting all subjects of educational activity to scientific search, forming scientifically proven programs. modernization of professional activity both at the level of the educational institution and every teacher in particular.

One of the most significant drawbacks of the low efficiency of the traditional education system is the disintegration of its elements. The process of disintegration can be traced both horizontally, reflecting the basic principles of formation of meaningful modules of training courses, and fixes vertically the connection of elements of the system of professional training of specialists, in particular, educational disciplines and their orientation to the logic of professional formation of the future specialist in higher education.

Professional training of a specialist will be productive only on condition that it will be formed as a real system, all components of which will be maximally integrated into a single whole and oriented towards the realization of basic professionally significant goals. Each subject must form its substantive and procedural basis, taking into account the professional specialization of vocational training.

Integration can be carried out on a substantive as well as procedural-activity field and at its core should be a high educational goal - to form a student's personality, capable of selfrealization in the process of professional development.

A significant indicator (from which it is known) of successful space of educational institution is psychological atmosphere. Its features are: intense, intense intellectual work of students; concerted interaction, creative collaboration; correctness in interpersonal relations, pedagogical tact, mutual respect; a sense of psychological comfort, freedom, security of each participant in the educational process [8].

The personal orientation of the educational process in your higher education institution implies an individual trajectory of each student's movement on the way to achieving the intermediate and final goals of vocational training. This can be possible only on condition that the student is able to formulate his strategy of educational activity, accumulate in himself the processes of purpose, self-discovery and self-determination, the choice of methods, forms, as well as the mode of work, optimal for him, oriented to his personal potential. Of course, this is a large-scale reformation, which involves the transition to a new educational formula, in which the student from the position of a performer working on a single, common for all educational program, moves to the position of an active subject, creator of an individual program with a dominant element of professional self-development [7].

The greatest value of the above-mentioned is seen in the way that the individual style of future activity is formed and acts as an absolute sign of professionalism of any direction; mechanisms of self-regulation of educational activity are formed, which are able to ensure continuity of the 
further process of professional formation, self-development in all significant aspects.

It is important to identify the integrating blocks that most closely reflect the essence of the profession and can create a truly operational system, that is, occupy the status of a system-forming entity; as well as key competencies as a basis for ensuring that the professional education system of the specialist is adequately targeted.

Undoubtedly, the orientation to competence changes fundamentallythe essence of the vocational education system, designing a fundamentally different end result.

Conclusion. Thus, the competence approach and integrity in the modern educational space, the integrity of the educational process in educational institutions are priority components of the quality of modern education, important vectors for the success of modern specialists in all areas, in particular, in the field of art.

Research prospects. Further investigation of innovative mechanisms of professional training of modern specialists, blocks of integration in the educational space, research of effective international experience is expedient.

\section{References}

1. Franchuk T.Y. The whole educational space: pedagogical foundations of its formation: monograph / T.Y. Franchuk; Kamianets-Podilskyi nationaluniversity named after I. Ohienko. - Kamianets-Podilskyi, 2009. - 244 p.

2. Guk O.F. Value orientations of education in the context of European integration / O.F. Guk // Scientific Bulletin of Chernivtsi University. Issue 433. Series 'Pedagogy and Psychology', 2009. - P. 92 - 103.

3. The philosophical and methodological principles of improving the quality of higher education in Ukraine: the European dimension / ed. col .: V. Andrushchenko (director), M. Boychenko, L. Gorbunova, I. Nadolnyi and others. - K .: Pedagogical Thought, 2012. - 220 p.

4. ZhuravskyiV. S. Higher education as a factor of state formation and culture in Ukraine / V.S. Zhuravskyi // Institute of State and Law named after V.M. Koretskyi of NAS of Ukraine, Institute of Higher Education of APS of Ukraine. - K .: View. In Yure House, 2003. - 416 p.
5. Guk O.F. Processes of globalization and prospects of formation of the world system of university education / O.F. Guk // Actual problems of sociology, psychology, pedagogy Collection of scientific works. Issue 12 K.: Phoenix. 2011. - P. $116-121$

6. Guk O.F., Chernukha N.M. Priority vectors of modern education / O.F. Guk, N.M. Chernukha // Topical issues of socialpedagogy: Collective monograph. -CARICOM, Barbados, 2017. - P. 30-55. Monograph ISBN 978-0-9955865-1-2

7. Educational technologies: Teaching method. manual / O.M.Piekhota A.Z. Kiktenko, O.M. Lubarska and others; Ed. O.M. Piekhota. - K .: A.S.K, $2001-256 p$

8. Bekh I.D. Personally oriented education. Scientific and methodological manual. I. D. Beh. - K .: IZMN, 1998. - 204 p.

Список використаних джерел:

1. Франчук Т. Й. Цілісний освітній простір: педагогічні основи його формування: монографія / Т. Й. Франчук; Кам'янець-Поділ. нац. ун-т ім. І. Огієнка. - Кам'янець-Поділ, 2009. - 244 с.

2. Гук О.Ф. Ціннісні орієнтації освіти в контексті євроінтеграції О.Ф. Гук // Науковий вісник Чернівецького університету. Випуск 433. Серія "Педагогіка та психологія", 2009. - С. 92 - 103.

3. Філософсько-методологічні засади підвищення якості вищої освіти України : європейський вимір / авт. кол.: В. Андрущенко (керівник), М. Бойченко, Л. Горбунова, І. Надольний та ін. - К.: Педагогічна думка, 2012. $-220 \mathrm{c}$

4. Журавський В. С. Вища освіта як фактор державотворення і культури в Україні / В. С. Журавський // Ін-т держави і права ім. В. М. Корецького НАН України, Ін-т вищої освіти АПН України. - К.: Вид. дім "Ін Юре", 2003. - 416 c.

5. Гук О.Ф. Процеси глобалізації і перспективи формування світової системи університетської освіти / О.Ф. Гук // Актуальні проблеми соціології, психології, педагогіки. Збірник наукових праць. Вип..12.- К.: Фенікс. 2011. - C. $116-121$

6. Гук О.Ф., Чернуха Н.М. Пріоритетні вектори сучасної освіти / О.Ф. Гук, Н.М. Чернуха // Topical issues of socialpedagogy: Collective monograph. - CARICOM, Barbados, 2017. - C. 30-55. Монографрія ISBN 978-0-9955865-1-2

7. Освітні технології: Навчал.метод. посібник / О.М. Пєхота, А.З. Кіктенко, О.М. Любарська та ін.; За заг. Ред. О.М. Пєхоти. - К.: А.С.К.,. 2001. $-256 \mathrm{c}$.

8. БехІ. Д. Особистісно зорієнтоване виховання. Науково-методичний посібник /. І. Д. Бех. - К.: ІЗМН, 1998. - 204 с.

Received November 29, 2018 Reviewed December 05, 2018

Н. Чернуха, д-р пед. наук проф.

Київський національний університет імені Тараса Шевченка, Київ, Україна

ORCID iD 0000-0002-5250-2366

Алі Шахейд Анад, доктор викладач

Південний технічний університет, Насірійський технічний інститут, Ірак

ORCID iD 0000-0002-1436-6332

\section{ПРІОРИТЕТНІ ВЕКТОРИ ПРОФЕСІЙНОЇ ПІДГОТОВКИ СУЧАСНИХ ФАХІВЦІВ ОБРАЗОТВОРЧОГО МИСТЕЦТВА}

В статті розглядаються пріоритетні вектори професійної підготовки сучасних фахівців образотворчого мистецтва у освітньому середовищі закладів вищої освіти. Зазначено, що на сучасному ринку праці роботодавців цікавить не набір теоретичних знань, а професійна компетентність, яка є підґрунтям успішної професійної самореалізації сучасних фахівців, зокрема і фахівців образотворчого мистецтва, що допомагає їм успішно вирішувати завдання у соціально-педагогічній діяльності, що є невід'ємною складовою професійного поля.

Досліджено та розкрито сутність компетентнісного підходу в професійній підготовці фахівців як важливої методології реформаційних та модерзаційних змін. Зазначено, що процес професійної підготовки фахівців образотворчого мистецтва потребує певних змін у ряді сегментів освітньої теорії і практики: в цінностях в меті, в результатах освітнього процесу, в його змісті, формах, методах, засобах освіти у взаємодії із зовнішнім середовищем. Акцентовано увагу на тому що професійна підготовка фахівця образотворчого мистецтва буде продуктивною за умови що вона буде сформована як цілісна система, всі компоненти якої будуть максимально інтегровані в єдине ціле і орієнтовані на реалізацію базових професійно значущих цілей, практичної діяльності сучасних фахівців у соціально-педагогічній практиці.

Обгрунтовано важливість успішного соціального простору освітнього закладу у процесі якісної підготовки фахівців образотворчого мистецтва, визначено ознаки сучасного соціального простору: інтелектуальна робота студентів, узгоджена взаємодія, творча співпраця, коректність міжособистісних відносин, взаємоповага, психологічний комфорт, свобода, безпека кожного учасника освітнього процесу.

Ключові слова: компетентність, освітній простір, сучасний фахівець, цілісність, професійна підготовка.

Н. Чернуха, д-р пед. наук, проф.

Киевский национальный университет имени Тараса Шевченко, Киев, Украина

ORCID iD 0000-0002-5250-2366

Али Шахейд Анад, доктор лектор

Южный технический университет, Нассирийский технический институт, Ирак

ORCID iD 0000-0002-1436-6332

\section{ПРИОРИТЕТНЫЕ ВЕКТОРЫ ПРОФЕССИОНАЛЬНОЙ ПОДГОТОВКИ СОВРЕМЕННЫХ СПЕЦИАЛИСТОВ ИЗОБРАЗИТЕЛЬНОГО ИСКУССТВА}

В статье рассматриваются приоритетные векторы профессиональной подготовки современных специалистов в образовательной среде высших учебных заведений. Раскрыта сущность компетентностного подхода, определены структурные составляющие в процессе профессиональной подготовки. Акцентировано внимание на целостности образовательного процесса в современных учреждениях высшего образования.

Ключевые слова: компетентность, образовательное пространство, современный специалист, целостность, професійна підготовка. 